\title{
Editorial: The Pot and the Kettle
}

And now abideth Bloom, Boyer, Bellow, these three; and the greatest of these is Bellow. They display a diversity of gifts, and not quite the same spirit. What unites them is a sense of mission and a preoccupation with the Crisis of Our Time, that is to say (they all agree) the Crisis in the University.

Allan Bloom is weakest in faith and hope. The title and subtitle of his recent book show how heavy his heart lies: The Closing of the American Mind: How Higher Education has Failed Democracy and Impoverished the Souls of Today's Students. One half of his prefatory disclaimer carries more conviction than the other: 'I am not moralizing; I no more want to be Jeremiah than Pollyanna'. Some of the targets of his dismissive ironies might distinguish the will from the deed: careerist undergraduates, seeking only income and status; professors of esotericism (Derrida et hoc genus omne); relativists and subjectivists and sceptics; teachers and students of business administration, who visit the liberal arts only as tourists; and all authors and exponents of abstract general theories that are 'produced in a day and not properly grounded in experience, but seem to explain things and are useful crutches for finding one's way in a complicated world'. This anathema is pronounced against 'Marxism, Freudianism, economism, behaviouralism' and all else that tempts us 'to prefer the shiny new theory to the fully cognized experience'.

Humane studies that deserve to survive are being choked by the natural and social sciences:

The third island of the university is the almost submerged old Atlantis, the humanities. In it there is no semblance of order, no serious account of what should and should not belong, or of what its disciplines are trying to accomplish or how. It is somehow the repair of man or of humanity, the place to go to find ourselves now that everyone else has given up. But where to look in this heap of jumble? It is difficult enough for those who already know what to look for to get any satisfaction here. For students it requires a powerful instinct and a lot of luck. The analogies tumble uncontrollably from my pen. The humanities are like the great old Paris Flea Market where, amidst masses of junk, people with a good eye found castaway treasures that made them rich. Or they are like a refugee camp where all the geniuses driven out of their jobs and countries by unfriendly regimes are idling, either unemployed or performing menial tasks. 


\section{Editorial}

The other two divisions of the university have no use for the past, are forward-looking and not inclined toward ancestor worship.

Some of the uncontrollable tumbling might remind an idling genius of what the pot said to the kettle in the great old Paris Flea Market.

Ernest Boyer is blander, and is willing to be recognized as forward looking, but he too is out to change the status quo in some similar directions. Here again the title is the message: College: The Undergraduate Experience in America. This report by the Carnegie Foundation for the Advancement of Teaching follows up the Foundation's earlier study High School. Again Dr Boyer seems to be editor and compiler more than author. The two reports are based on detailed research in scores of schools, colleges and universities. The manner as much as the content reveals the history of the man. He is not, like Professor Bloom, a choleric scholar and laudator temporis acti, but primarily an administrator and fund raiser and reformer, reflecting his career as Dean, Chancellor, educationist, and United States Commissioner for Education in the last Democratic administration. If America had Royal Commissions, Dr Boyer and his colleagues would be one. Their tone is exactly right: there is nothing fundamentally wrong with America or Americans or their schools and colleges; if we take thought, make an effort, all pull together, all will be well. What is needed is a plan, a recipe, almost - one begins to fear-a shiny new theory rather than a fully cognized experience.

Some of the culprits are the same, but the crimes are different. Professors in research universities are too specialist and scholarly, insufficiently concerned with students' personal development and vocational preparation. Old standards of accuracy and literacy need to be revived. Foreign languages must be taught again. There is a need for a core curriculum. Literature will have its place-in the middle of the road:

From Sophocles' Antigone to Arthur Miller's Death of a Salesman Western society expresses its most profound tensions when it affirms that men and women are not means, but ends, and yet, that the individual must, at times, be guided by community. Balancing these two values - sometimes complementary, sometimes conflicting-is the tightrope of history upon which our society walks. By leaning too much in one direction, anarchy will result; leaning too much into the other, the outcome is totalitarianism.

The best eight pages in either of these books are the Foreword by Saul Bellow to Bloom's Dunciad. Mr Bellow treads no middle way, because be knows at first hand the role of the writer and the thinker in 'society': 
Romantic poets and other edifying theorists of the nineteenth century had it wrong-poets and novelists will never be the legislators and teachers of mankind. That poets - artists - should give new eyes to human beings, inducing them to view the world differently, converting them from fixed modes of experience, is ambition enough, if one must offer a purposive account of the artist's project. What makes that project singularly difficult is the disheartening expansion of trained ignorance and bad thought. For to put the matter at its baldest, we live in a thought-world, and the thinking has gone very bad indeed. Therefore the artist, whether or not he views himself as an intellectual, is involved in thought-struggles. Thinking alone will never cure what ails him, and any artist should be grateful for a naive grace which puts him beyond the need to reason elaborately.

This will be misread as an attack on reason, or on elaborate reasoning, although the whole paragraph and the whole Foreword is about the dangers of bad thinking and hence about the importance of good thinking. As Saul Bellow knows, the answer is to say it again, and sometimes less directly, as he did when he ascribed to Herzog the remark that 'What this country needs is a good five-cent synthesis'. 